УДК 377.5

DOI:

Ольга Яковчук, кандидат педагогічних наук, старший викладач кафедри технології в ресторанному господарстві та готельної і ресторанної справи Донецького національного університету економіки і торгівлі імені Михайла Туган-Барановського

\title{
ПЕРСПЕКТИВИ РОЗВИТКУ ДУАЛЬНОЇ СИСТЕМИ ЗДОБУТТЯ ВИЩОЇ ОСВІТИ В УКРАЇНІ
}

У статті розглядаються особливості та механізми впровадження дуальної форми здобуття вищої освіти в Україні. Проведено аналіз ії переваг та недоліків. Вивчено позитивний досвід впровадження дуальної освіти у різних країнах світу. Визначено вимоги до основних учасників дуального прочесу, принципи їх взаємодіі. Серед основних переваг дуальної форми здобуття вищої освіти визначено: наближення навчального процесу до вимог виробництва, посилення практичної спрямованості освітнього процесу, посилення інноваційної діяльністі закладів вищої освіти, підвищення мотивації студентів до набуття знань, посилення зачікавленості керівників підприємств та установ у навчанні кваліфікованих кадрів та фінансуванні навчальних закладів.

Ключові слова: вища освіта; якість освіти; дуальна форма здобуття освіти; освітній процес; учасники дуальної форми навчання; держава; підприємство; роботодавець; майбутній фахівець.

Рис. 1. Табл. 1. Літ. 9.

Olha Yakovchuk, Ph.D.(Pedagogy), Senior Lecturer of the Technology in the Restaurant Industry and in the Hotel and Restaurant Business Department

Donetsk Mykhaylo Tuhan-Baranovskiy National University of Economics and Trade

\section{PROSPECTS FOR DUAL EDUCATION DEVELOPMENT IN UKRAINE}

The article covers the conditions of realization of vocational education according to dual system in Ukraine. There were analyzed the principal advantages and disadvantages of this system.

The development of the economic system in Ukraine involves the labour market modernization and raising the level of population employment. Labour market of young professionals is an important component of the state's economic sector. After all, it is the young people who have the potential to accelerate the state's development dynamics.

According to the statistics of the State Employment Service of Ukraine the unemployment rate among young people increases annually. Among the reasons for the low level of higher education institutions the graduates' employment can be pointed out the theoretical training imperfection, lack of practical experience and the low level of working activity skills formation. The labour market requires not only professionals with special aptitude, but highly-qualified professionals capable of innovation as well. Under such conditions, the problem of future specialists training system reorganization, new educational models introduction into the educational process, and the improvement of the mechanisms of interaction between education and the labour market arises. One of the factors in solving this problem is the introduction of higher education dual form. It involves a combination of the students' theoretical and practical training, provides an opportunity to reorient the educational goals and objectives in accordance with the employers' requirements.

A dual system is not an innovation. It was started in Germany in the 70s of the twentieth century. Today, the dual form of education effectively operates in many European countries (Belgium, Austria, Finland, Sweden, etc.). It is conceptually important that a state, an educational institution and an enterprise are together the participants in dual education, and the system of specialists training corresponds to the uniform requirements of all interested parties. Among the advantages of dual education are the following: elimination of contradictions between empirical knowledge and future professional activity, acquired competencies and occupational characteristics; formation of the students' strong-willed motivation to acquire professional skills; close relationship between the educational institution and the enterprise; receiving time-sensitive information on the latest trends in the labour market by the educational institution.

Keywords: higher education; dual study mode; an educational process; dual education participants; a state; enterprise; an employer; a future specialist.

$\Pi$ остановки Конкурентоспроможність держави на світовому ринку визначається позитивною динамікою інтеграційних процесів, розвитком соціальної сфери та ринкової економіки. Розвиток економічного та промислового сектора в Україні передбачає модернізацію ринку праці та підвищення рівня зайнятості населення. 


\section{ПЕРСПЕКТИВИ РОЗВИТКУ ДУАЛЬНОЇ СИСТЕМИ ЗДОБУТТЯ ВИЩОЇ ОСВІТИ В УКРАЇНІ}

Ринок праці молодих фахівців - важлива складова економіки держави. Адже, саме молодь володіє потенціалом, здатним прискорювати динаміку розвитку та інтеграційні процеси у державі.

Згідно з статистичними даними Державної служби зайнятості України рівень безробіття серед молоді щороку збільшується. Серед причин низького рівня працевлаштування випускників закладів вищої освіти можна відзначити недосконалість теоретичної підготовки, відсутність практичного досвіду роботи та низький рівень сформованості навичок трудової діяльності. Ринок праці потребує не просто фахівців, що мають певні знання чи вміння, але й висококваліфікованих спеціалістів, здатних до інноваційної діяльності.

За таких умов постає проблема реорганізації системи підготовки майбутніх фахівців, впровадження в навчальний процес нових освітніх моделей, удосконалення механізмів взаємодії освіти та ринку праці $[2,1-2]$. Одним з факторів iii розв'язання $\epsilon$ впровадження дуальної форми здобуття вищої освіти. Вона передбачає поєднання теоретичної та практичної підготовки студентів, надає можливість переорієнтувати навчальні цілі та завдання освітнього процесу відповідно до вимог роботодавців.

Концептуально важливо, що учасниками дуальної освіти одночасно є держава, навчальний заклад та підприємств, а система підготовки фахівців відповідає єдиним вимогам всіх зацікавлених сторін.

Аналіз останніх досліджень і публікацій. У науковій літературі різноманітні аспекти формування професійної компетентності майбутніх фахівців розглядаються в працях Ю. Бабанського, В. Безпалька, О. Бернацької, С. Архангельського, І. Дичковської, М. Катаєвої, В. Кушнір, В. Сластьоніна, В. Штоффа, В. Байденка.

Питання професійного самовизначення особистості досліджуються Н. Касаткіною, С. Чистяковою. Вивченню проблем безперервної професійної освіти, орієнтованої на підготовку конкурентоспроможних фахівців, присвячені роботи Н. Кузьміної, М. Нікітіна.

Дослідники Ю. Левицький, О. Голіченко, О. Амоша, Г. Китова розглядають проблеми соціального партнерства та ефективної взаємодії науки, освіти та промисловості шляхом створення науково-освітніх комплексів, асоціації. Проблеми підготовки конкурентоздатних фахівців на основі соціального партнерства розкриваються в працях Н. Ничкало, Л. Сушенцевої.

Наукові дослідження з питань оновлення та удосконалення традиційних форм здобуття вищої освіти останнім часом набувають нової значущості та актуальності (Г. Федотова, М. Дернова, Г. Постоян, О. Романовський). Однією з інновацій освіти вчені визначають дуальну форму здобуття вищої освіти.

Незважаючи на світове визнання дуальності, проблема запровадження дуальної форми здобуття вищої освіти в Україні не була предметом спеціальних досліджень. Детально вивчено та обгрунтовано лише окремі аспекти впровадження професійної дуальної освіти. Потребують детального обгрунтування шляхів та механізмів впровадження цієї форми освіти у вищих навчальних закладах в Україні.

Мета дослідження - проаналізувати перспективи впровадження дуальної форми здобуття вищої освіти в Україні, обгрунтувати іiі можливості порівняно з традиційним навчанням.

Виклад основного матеріалу дослідження. Удосконалення системи вищої освіти в Україні, її інтеграція в освітній простір Свропи передбачає підвищення конкурентоспроможності майбутніх фахівців. Результатом навчання студентів має бути готовність до застосування набутих знань, вмінь та навичок у конкретних технологічних та виробничих ситуаціях. Саме дуальна форма здобуття освіти забезпечує якісний розвиток системи освіти, актуалізує накопичення знань для розвитку промислового сектору держави.

Дуальність передбачає існування двох носіїв освіти (навчального закладу та підприємства), що злагоджено співпрацюють та забезпечують якісні підготовку майбутніх фахівців.

Дуальна форма освіти інтегрує теоретичне навчання студентів узакладах освіти із навчанням на робочих місцях (на підприємствах, в організаціях, установах), тобто поєднує теорію та практичну складову освітнього процесу. Навчання у закладі вищої освіти чергується 3 періодами виробничої діяльності. При цьому, загальна теоретична підготовка майбутніх фахівців відбувається у закладі освіти, а практична - на робочих місцях. За таких умов освітній процес $\epsilon$ максимально наближеним до вимог виробництва.

Варто погодитись 3 думкою Н. Абашкіної, яка вважає, що дуальна система забезпечує рівновагу між попитом і пропозицією фахівців на ринку праці та передбачає "підготовку саме такої кількості фахівців і такої якості знань та вмінь, якої в певний час потребує ринок праці” $[1,107]$.

Дуальна освіта не є інновацією. Вона була започаткована у Німеччині в семидесятих роках двадцятого сторіччя. Наразі така форма освіти ефективно функціонує в багатьох європейських 


\section{ПЕРСПЕКТИВИРОЗВИТКУ ДУАЛЬНОЇ СИСТЕМИ ЗДОБУТТЯ ВИЩОЇ ОСВІТИ В УКРАЇНІ}

странах (Бельгії, Австрії, Фінляндії, Швеції тощо).

Сучасна система дуальної освіти Німеччини забезпечує навчання у професійній школі та в дуальних закладах вищої освіти. Дуальна освіта передбачає існування навчального (дуальний заклад вищої освіти) та виробничого (приватне підприємство) освітнього середовища. Підприємство $\epsilon$ партнером закладуосвіти та організовує практичну підготовку студентів. Правові відносини носіїв дуальної освіти закріплені на законодавчому рівні. Ефективність такої освіти відповідає потребам держави, особистості, сектору обслуговування та виробничого сектору [5, 8-9].

Заклади вищої освіти Польщі також пропонують дуальну форму навчання, що поєднує освітній процес із отриманням студентами практичного досвіту за обраною спеціальністю. Під час такої інтегрованої системи дуального навчання, студенти тричі на тиждень відвідують академічні заняття, інші дні відводяться для проходження практики та отримання досвіду роботи в установах. Проходження такої практики фінансується установами чи організаціями, що дозволяє студентові сплатити власне навчання.

Дуальна освіта в Австрії, Швейцарії та Фінляндії реалізується через поєднання академічного та професійного навчання майбутніх фахівців у різних організаціях та установах. Теоретична частина освітнього процесу студентів складає близько $30 \%$ часу, тоді як виробнича більше $60 \%$.

Дуальні програми у цих країнах мають такі особливості:

- чергування періодів теоретичної підготовки та практики протягом всього навчання; теоретичне навчання інтегроване 3 практичною діяльністю майбутніх фахівців на підприємствах;

- відповідність змісту навчальних програми вимогам конкретного дуального підприємствапартнера закладу освіти;

- закріплення за студентами фахівцівнаставників 3 числа провідних фахівців підприємства;

- фінансова участь підприємства в забезпеченні практичного навчання студентів;

- участь студентів у навчальних проектів не тільки у закладі освіти, але й на робочих місцях.

Останнім часом проблема дуальності освіти набуває все більшої популяризації в Україні. Серед основних завдань іiі впровадження можна визначити: підвищення якості підготовки кадрів iз урахуванням вимог потенційних роботодавців, оновлення професійних програм, форм та методів навчання, подолання відриву між теоретичною та практичною складовою освітнього процесу.
Дуальна освіта сприяє професійному становленню особистості, iï розвитку та самовизначенню, формуванню готовності до виконання виробничих дій. За такої форми навчання набуття професійних компетентностей відбувається при виконанні виробничих дій, а розвиток особистості відбувається в умовах диференційованого навчання.

Перспективи дуальної форми навчання пояснюються взаємною зацікавленістю держави, закладу освіти та дуального підприємства у підготовці високоякісних фахівців. Так, дослідники П. Собєчовська та М. Майч відзначають, що надійність дуальної освіти пов'язана із “задоволенням потреб як самих студентів, так і цілей підприємства або організації”' [6, 267 - 268]. Науковець С. Амеліна наголошує на “значному попиті на фахівців, підготовлених у системі дуальної освіти" [3, 109].

Особливості становлення та перспективи розвитку дуальної форми здобуття освіти в Україні пов'язані 3 чіткою взаємодією та зацікавленістю всіх учасників дуального процесу.

Взаємодія учасників дуальної форми здобуття вищої освіти базується на принципах соціального партнерства та чіткого виконання вимог дуальності [4, 58 - 59]. Зокрема, державні служби та органи розробляють нормативно-правове забезпечення, координують взаємодію всіх учасників дуального процесу та сприяють розвиткові їх мотивації. Керівництво та провідні фахівці дуального підприємства формують запит на підготовку спеціалістів певного профілю, визначають вимоги до кваліфікації та професійної компетентності майбутніх фахівців, контролюють практичну діяльність студентів на підприємстві, приймають участь в оцінюванні якості знань студентів, забезпечують працевлаштування випускників.

Заклад вищої освіти модернізує та інтегрує освітній процес, відповідно до вимог виробництва, розробляє та удосконалює навчальні програми, забезпечує взаємодію з роботодавцями.

Взаємодія учасників дуальної форми здобуття освіти представлена на рис. 1.

Аналіз основних принципів та механізмів побудови взаємозв'язків між сторонамиучасниками дуального процесу надав можливість уточнити формулювання поняття “дуальна освіта". Під дуальною освітою розуміємо спосіб взаємодії між закладом освіти та підприємствами певної галузі, що беруть на себе зобов'язання здійснювати підготовку студентів.

Результативність впровадження дуальної 


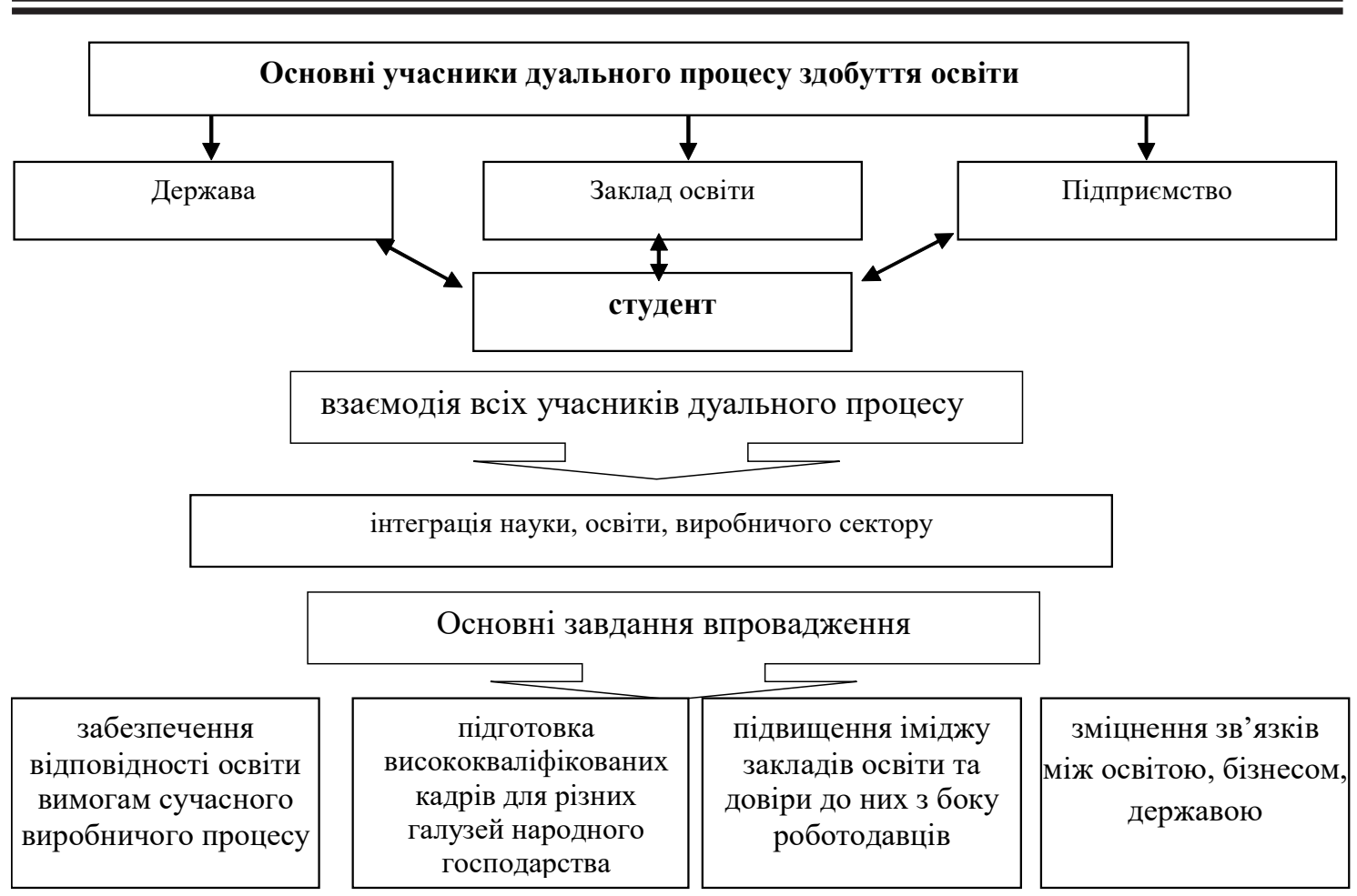

Рис. 1. Взаємодія учасників дуальної форми здобуття освіти

форми здобуття освіти залежить від ряду критеріїв: розробки нормативно-правових документів та єдиної інформаційної бази для функціонування системи “держава-заклад освітипідприємство”, модернізації практичної частини освітнього процесу. Відповідності підготовки студентів єдиним вимогам виробництва, забезпечення працевлаштування студентів на підприємствах.

Основними умовами впровадження дуальної форми здобуття вищої освіти вважаємо:

- наявність базових підприємств та установ, що $є$ дуальними партнерами закладів вищої освіти;

- розробку програм взаємодії навчальних закладів та підприємств (організацій, компаній, установ);

- введення стажування викладачів закладів освіти на підприємствах;

- залучення потенційних роботодавців та представників підприємств до реалізації освітніх програм.

Серед переваг дуальної форми здобуття вищої освіти варто відзначити:

- наближення освітнього процесу до вимог виробництва;

- підвищення цінності та соціальної значущості навчання;

- посилення практичної спрямованості освітнього процесу.
- орієнтування навчання на формування спеціальних фахових умінь та навичок майбутніх фахівців, що дозволяє усунути один з основних недоліків традиційних форм та методів навчання: відокремленість теоретичного матеріалу від практичної складової;

- підвищення мотивації студентів до набуття знань, необхідних для майбутньої професійної діяльності;

- покращення якості набутих студентами знань, вмінь та навичок;

- зростання зацікавленості керівників підприємств та установ у навчанні кваліфікованих кадрів;

- підвищення рівня фінансування закладів освіти та зміцнення їх матеріально-технічної бази за рахунок виробничого сектору;

- посилення інноваційної діяльність закладів освіти.

Навчальні програми дуальних закладів вищої освіти є професійно спрямованими. Вони можуть бути диференційовані на блоки: теоретичного навчання (у закладі освіти), самостійної роботи, виробничого навчання та кваліфікаційноробітничий (на підприємстві). Практична частина такого навчання відбуватиметься в реальних умовах виробничого процесу, а засвоєння знань та вмінь студентами за участю наставників 3 підприємств. Під час навчання студенти також матимуть змогу засвоїти робітничу професію. 


\section{Порівняльна характеристика традиційної та дуальної системи здобуття освіти}

Таблиця 1.

\begin{tabular}{|c|c|}
\hline Традиційна система освіти & Дуальна форма здобуття освіти \\
\hline $\begin{array}{l}\text { Формування замовлення на підготовку фахівців } \\
\text { здійснює держава }\end{array}$ & $\begin{array}{l}\text { Пріоритет у формуванні замовлення на підготовку } \\
\text { фахівців має підприємство }\end{array}$ \\
\hline $\begin{array}{l}\text { Теоретична та практична складові освітнього } \\
\text { процесу є відокремленими }\end{array}$ & $\begin{array}{l}\text { Узгоджене поєднання теоретичної п підготовки } \\
\text { майбутніх фахівців }\end{array}$ \\
\hline $\begin{array}{l}\text { Набуття студентами практичних вмінь та навичок } \\
\text { здебільшого відбувається під час проходження } \\
\text { різних видів практики }\end{array}$ & $\begin{array}{l}\text { Поступове удосконалення практичних вмінь та } \\
\text { навичок відбувається протягом всього періоду } \\
\text { навчання }\end{array}$ \\
\hline $\begin{array}{l}\text { Програма та завдання виробничої практики не } \\
\text { відповідають вимогам потенційних роботодавців }\end{array}$ & $\begin{array}{l}\text { Виробнича практика максимально наближена до } \\
\text { вимог підприємства-дуального партнера закладу } \\
\text { вищої освіти }\end{array}$ \\
\hline $\begin{array}{l}\text { Фінансове забезпечення навчання відбувається за } \\
\text { рахунок коштів держави }\end{array}$ & $\begin{array}{l}\text { Фінансове забезпечення навчання частково } \\
\text { відбувається за рахунок роботодавця чи дуального } \\
\text { підприємства }\end{array}$ \\
\hline $\begin{array}{l}\text { Великий } \quad \text { адаптаційний } \\
\text { працевлаштуванні випускників }\end{array}$ & $\begin{array}{l}\text { Значне скорочення адаптаційного періоду при } \\
\text { працевлаштуванні }\end{array}$ \\
\hline $\begin{array}{l}\text { Працевлаштування випускників закладу вищої } \\
\text { освіти не гарантовано }\end{array}$ & Працевлаштування гарантовано \\
\hline
\end{tabular}

Порівняльна характеристика традиційної та дуальної системи здобуття освіти наведена у таблиці 1.

Разом $з$ тим, варто відзначити проблеми впровадження дуальної форми здобуття вищої освіти: необхідність удосконалення законодавчого забезпечення дуального процесу, труднощі у модернізації навчальних програм закладів освіти до вимог виробництва, обов'язкову перекваліфікацію працівників підприємств, без педагогічної досвіду, у наставників студентів.

Висновок. Підсумовуючи викладене вважаємо дуальну форму здобуття вищої освіти продуктом соціального партнерства між навчальним закладом та підприємством. Така форма здобуття освіти має ряд переваг перед традиційним навчанням (дає змогу подолати суперечності між емпіричними знаннями та майбутньою професійною діяльністю студентів, набутими під час навчання компетентностями та професійними характеристиками, сприяє підвищенню якості знань майбутніх фахівців, забезпечує конкурентоспроможність випускників навчальних закладів на ринку праці, частково вирішує проблеми фінансування освіти за рахунок коштів підприємства, розширює інноваційну діяльність закладів освіти).

\section{ЛІТЕРАТУРА}

1. Абашкіна Н. В. Принципи розвитку професійної освіти в Німеччині: монографія / Н.В. Абашкіна. - К.: Вища школа, 1998. - 207 с.

2. Андрущенко В.П. Теоретико-методологічні засади реформування вищої освіти в Україні / В.П.Андрущенко // Педагогічна газета. Академія пед. наук України. - №12 (78), грудень 2000 p. - C.1-2.

3. Амеліна С. М. Особливості дуальної системи вищої професійної освіти у навчальних закладах Німеччини / С.М. Амеліна // Зб. наук. праць “Проблеми трудової і професійної підготовки". - 2010. - Вип. 15 - С. 107-112.

4. Дудкін П., Дудкіна О. Формування та розвиток регіональних інноваційних структур як нова парадигма співпраці вищих навчальних закладів і бізнесу //Соціально-економічні проблеми і держава. - 2013. - Вип. 2 (9). C. $58-66$.

5. Липкина И. Н. Система образования взрослых в Германии: учеб.- метод. пособие / И.Н. Липкина, В.П. Тарантей. - Гродно: ГрГУ, 2001. $-104 \mathrm{c}$.

6. Sobiechowska, P. \& Maisch. "Work-based learning: in search of an effective model", Educational Action Research / Sobiechowska, P. \& Maisch. - M., 2006. - vol. 14, no. 2. - p. 267-268.

\section{REFERENCES}

1. Abashkina, N.V. (1998). Pryntsypy rozvytku profesiinoi osvity $v$ Nimechchyni [Principles of vocational education development in Germany]. Kyiv: Vyshcha shkola, 207 p. [in Ukrainian].

2. Andrushchenko, V. P. (2000). Teoretykometodolohichni zasady reformuvannia vyshchoi osvity v Ukraini [Methodological Principles for Reforming Higher Education in Ukraine]. 

ТЕХНОЛОГІЧНИЙЗАСІБ ФОРМУВАННЯПДПРИЕМНИЦЬКОЇ КОМПЕТЕНТНОСТІ

Pedagogical newspaper. Academy of Pedagogical Sciences of Ukraine. No.12 (78), pp.1-2. [in Ukrainian].

3. Amelina, S. M. (2010). Osoblyvosti dualnoi systemy vyshchoi profesiinoi osvity u navchalnykh zakladakh Nimechchyny [Features of the dual system of higher vocational education in educational institutions in Germany]. Collection of scientific researcher "Problems of labor and vocational training”. Vol. 15, pp. 107-112. [in Ukrainian].

4. Dudkin, P. \& Dudkina, O. (2013). Formuvannia ta rozvytok rehionalnykh innovatsiinykh struktur yak nova paradyhma spivpratsi vyshchykh navchalnykh zakladiv i biznesu [Features of the dual system of higher vocational education in educational institutions in Germany]. Socio-economic problems and the state. Vol. 2 (9), pp. 58-66. [in Ukrainian].

5. Lypkyna, Y. N. \& Tarantei, V. P. (2001). Systema obrazovanyia vzroslykh $v$ Hermanyy [Adult education system in Germany]. Hrodno: HrHU, 104 p. [in Ukrainian].

6. Sobiechowska, P. \& Maisch (2006). "Work-based learning: in search of an effective model", Educational Action Research. Vol. 14, no. 2, pp. 267-268. [in English].

УДК 334:377.5:378

DOI:

Вікторія Майковська, кандидат педагогічних наук, доцент кафедри маркетингу та торговельного підприємництва Харківського торговельно-економічного інституту КНТЕУ

Ігор Юрко, кандидат економічних наук, доцент, кафедри комериійної діяльності та підприємництва

ВНЗ Укоопспілки "Полтавський університет економіки і торгівлі"

\section{WОRКSНОР ЯК ІНСТРУМЕНТ ПРАКТИКО-ОРІЕНТОВАНОГО НАВЧАННЯ І МЕТОДИКО-ТЕХНОЛОГІЧНИЙ ЗАСІБ ФОРМУВАННЯ ПІДПРИСМНИЦЬКОЇ КОМПЕТЕНТНОСТІ}

У статті розглянуто теоретичні та практичні аспекти використання workshop в процесі професійної підготовки. Виявлено, що works hор характеризується інтенсивною груповою взаємодією, використанням наявного життєвого досвіду, отриманням динамічного знання та точковою тематичною спрямованістю, $i$ це робить його дієвим засобом формування підприємницької компетентності. Проведено аналіз теоретичних прачь вітчизняних та зарубіжних фахівців, який свідчить, щчо в них практико-орієнтований підхід представлено як базовий компонент процесу професійної підготовки, при иьому не порушується проблема застосування workshop як інструменту практико-орієнтованого навчання. Представлено досвід застосування workshop для розробки Регіональної програми розвитку підприємництва за участі студентів ВНЗ Укоопспілки "Полтавський університет економіки і торгівлі".

Ключові слова: економіка знань; професійна підготовка; практико-орієнтоване навчання; workshop; ключові компетентності; підприсмницька компетентність.

Лim. 11.

Victoriya Maykovska, Ph.D.(Pedagogy), Associate Professor of the Marketing and Trade Entrepreneurship Department Kharkov Trade and Economic Institute of Kyiv National University of Trade and Economics Ihor Yurko, Ph.D.(Economy), Associated Professor of the Commerce Activities and Entrepreneurship Department Poltava University of Economics and Trade

\section{WORKSHOP AS A TOOL OF PRACTICAL-BASED EDUCATION AND AS A METHODOLOGICALAND TECHNOLOGICAL MEAN OF ENTREPRENEURIAL COMPETENCE FORMATION}

During the last decade the workshop is the topic of discussion in the educational environment. The article deals with the theoretical and practical aspects of usage of the workshop in the process of professional training. It was established that the workshop is a tool of practical-based education and methodical and technological mean for a competent specialist formation. It was revealed that the workshop is characterized by the intensive group interaction, using existing life experience, dynamic knowledge obtaining and point thematic orientation, and this 